Int. J. Dev. Biol. 55: 33-43 (2011)

doi: $10.1387 / \mathrm{ijdb} .103233 \mathrm{sg}$

\title{
Regulation of programmed cell death during neural induction in the chick embryo
}

\author{
ANNA GIBSON ${ }^{1}$, NEIL ROBINSON, ANDREA STREIT², GUOJUN SHENG ${ }^{3}$ and CLAUDIO D. STERN* \\ Department of Cell and Developmental Biology, University College London, London, U.K.
}

\begin{abstract}
To study early responses to neural inducing signals from the organizer (Hensen's node), a differential screen was performed in primitive streak stage chick embryos, comparing cells that had or had not been exposed to a node graft for 5 hours. Three of the genes isolated have been implicated in Programmed Cell Death (PCD): Defender Against Cell Death (Dad1), Polyubiquitin II (UbII) and Ferritin Heavy chain (fth1). We therefore explored the potential involvement of PCD in neural induction. Dad1, Ubll and fth 1 are expressed in partly overlapping domains during early neural plate development, along with the pro-apoptotic gene Cas9 and the death effector Cas3. Dad1 and $\mathrm{Ubll}$ are induced by a node graft within 3 hours. TUNEL staining revealed that PCD is initially random, but both during normal development and following neural induction by a grafted node, it becomes concentrated at the border of the forming neural plate and anterior non-neural ectoderm and downregulated from the neural plate itself. PCD was observed in regions of Caspase expression that are free from Dad1, consistent with the known anti-apoptotic role of Dad1. However, gain- and loss-of-function of any of these genes had no detectable effect on cell identity or on neural plate development. This study reveals that early development of the neural plate is accompanied by induction of putative pro- and anti-apoptotic genes in distinct domains. We suggest that the neural plate is protected against apoptosis, confining cell death to its border and adjacent non-neural ectoderm.
\end{abstract}

KEY WORDS: dad, ubiquitin, PCD, apoptosis, neural plate, neural ectoderm

\section{Introduction}

Neural induction is the process by which signals emanating from cells in the "organizer" (Hensen's node in amniote embryos) instruct cells in the adjacent epiblast to acquire a neural fate and form the neural plate, from which the entire Central Nervous System (CNS) arises (Stern, 2005). Several lines of evidence implicate BMP inhibition as an essential step in neural induction (de Almeida et al., 2008, Harland, 2000, Hemmati-Brivanlou and Melton, 1997, Linker et al., 2009, Linker and Stern, 2004, Marchal et al., 2009, Reversade et al., 2005, Stern, 2006, Vonica and Brivanlou, 2006). However chick epiblast cells cannot respond to BMP inhibitors unless they have previously been exposed for at least 5 hours to other signals from the organizer (Linker and Stern, 2004, Streit et al., 1998).
To define this essential early step at the molecular level, we designed a differential screen between cells that either had or had not been exposed to a graft of Hensen's node for 5 hours (Streit et al., 2000). Among the genes isolated were several previously undescribed genes such as ERNI (Papanayotou et al., 2008, Streit et al., 2000) and Churchill (Sheng et al., 2003). Three of the genes correspond to the chicken homologues of known genes: Defender Against Cell Death 1 (Dad1), Polyubiquitin 2 (Ub/l) and Heavy chain Ferritin (fth1). Their products have been implicated in controlling cell death in other systems, raising the possibility

Abbreviations used in this paper: CNS, Central Nervous System; Dad, defender against cell death; fth, ferritin heavy chain; PCD, programmed cell death; Ub, ubiquitin

*Address correspondence to: Claudio D Stern. Department of Cell \& Developmental Biology, University College London, Gower Street, London WC1E 6BT, U.K. Fax: +44-20-7679-2091. e-mail: c.stern@ucl.ac.uk

Present addresses: ${ }^{1}$ MRC National Institute for Medical Research, The Ridgeway, Mill Hill, London NW7 1AA, U.K., ${ }^{2}$ Department of Craniofacial Development, King's College London, Guy's Campus, London SE1 9RT, U.K. and ' 'Lab for Early Embryogenesis, RIKEN Center for Developmental Biology, 2-2-3 Minatojimaminamimachi, Chuo-Ku, Kobe, Hyogo 650-0047, Japan

Supplementary Material (5 figures) for this paper is available at: http://dx.doi.org/10.1387/ijdb.103233sg

Accepted: 9 December 2010. Final author corrected PDF published online: 22 December 2010.

ISSN: Online 1696-3547, Print 0214-6282

(c) 2010 UBC Press

Printed in Spain 
that these genes, and regulation of apoptosis, may play a role at early stages of neural development.

Here we describe their expression patterns and the distribution of apoptotic cells during neural induction in the chick. Gain- and loss-of-function experiments suggest that these genes are not essential for neural plate formation. However, regulation of the spatial distribution of programmed cell death accompanies the early stages of neural induction along with the induction of expression of these genes. We suggest that the early neural plate is protected against apoptosis, restricting cell death to the border of the neural plate (from which the neural crest and placodes will eventually arise) and the adjacent anterior non-neural ectoderm.

\section{Results}

\section{Expression of Dad1, Ubll and Fth1 during neurulation}

Weak expression of Dad1 is first detected at mid-primtive streak stages (about stage 3 ), in a region corresponding approximately to the prospective neural plate (Fig. 1A), which then intensifies (Fig. $1 \mathrm{~B}, \mathrm{E})$. During neurulation and early somite stages, Dad1 is expressed predominantly in the forming neural plate, especially in the prospective neural crest (Fig. $1 \mathrm{D}, \mathrm{F}$, arrows in F) and more weakly in somites and the regressing primitive streak (Fig. $1 \mathrm{C}, \mathrm{D}, \mathrm{F}$ ).

$\mathrm{Ubll}$ is expressed in the anterior half of the epiblast at primitive streak stages, including the prospective neural plate and prospective neural plate border (Fig. $1 \mathrm{G}$ ). It then becomes concentrated at the anterior neural border (Fig. $1 \mathrm{H}$, I, arrow in K) and later to the neural tube (Fig. $1 \mathrm{~J}, \mathrm{~L}$ ) and migrating neural crest (arrowheads in Fig. 1J).

The expression of fth 1 is quite variable at early stages: at stages $3^{+}-5$ some embryos show fairly uniform staining throughout the area pellucida (Fig. 1M), others show expression concentrated in non-neural regions (excluding the presumptive neural plate; Fig. $1 \mathrm{~N}$ ) and yet others have expression in the future neural plate but not prospective epidermis (Fig. 10). The pattern becomes consistent after stage 7 , when the strongest expression is seen in developing blood islands and the developing neural plate (Fig. 1 P-R).

In conclusion, all three genes isolated from the differential screen for early responses to neural induction are expressed in the neural plate of normal embryos from late primitive streak to early neurulation stages. However they differ in their precise patterns and timing of expression.

\section{Gain- or loss-of-function of Dad1, Ubll or Fth1 has no effect on cell identity}

To assess whether these three genes influence cell fate choices at early stages of neural development, they were variously either misexpressed by electroporation and/or their function abrogated using dominant-negative constructs or morpholinos. Neither gain- nor loss-of-function of any of these genes had any effect on neural, epidermal or neural border marker expression (for details see Supplementary Information).

\section{Localization of cells undergoing apoptosis during normal development}

Dad1, Ubll and fth1 have all been implicated in the regulation of cell death (Cairo et al., 1995, Hong et al., 2000, Lee and Peter,

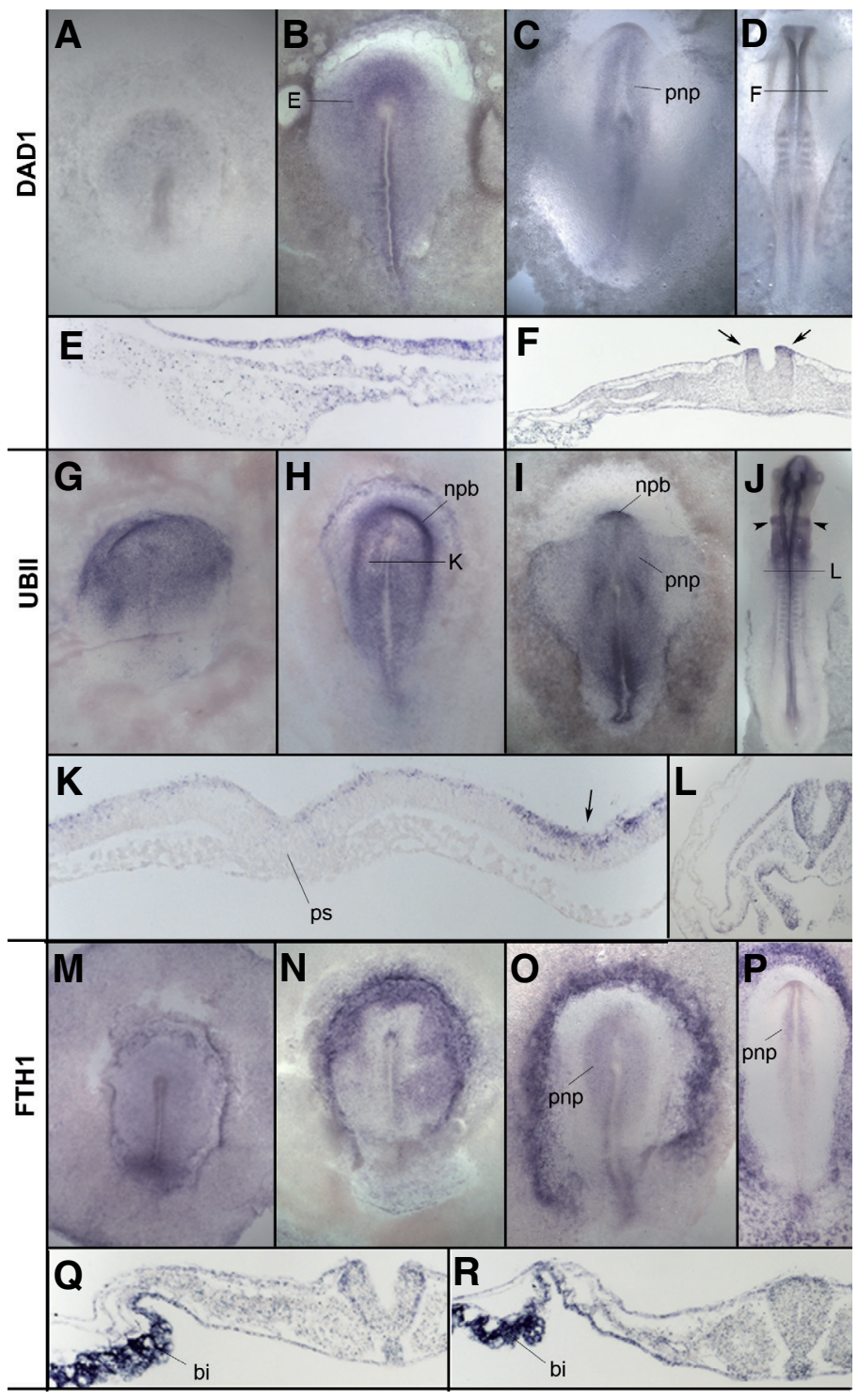

Fig. 1. Expression of Dad1, Ubll and Fth1. (A-F) Expression of Dad1 at stages 3 (A), 4 (B), 6 (C) and 8 (D) showing progressive restriction to the forming neural plate. Histological sections ( $E, F$, at the levels indicated in panels $B, D$ ) show that early expression is concentrated in the epiblast layer $(E)$ and that during neural plate formation expression is strongest at the neural plate border, in prospective neural crest (F, arrows). (G-L) Expression of Ubll. At early stages expression is seen in the prospective neural plate $\left(G\right.$; stage $\left.3^{+}\right)$, then becomes concentrated at its border $(H$; stage 5 and l, stage 6) and eventually throughout the entire nervous system including the migrating neural crest (arrowheads in J; stage 11). Transverse sections through embryos at stage 5 show expression concentrated in the neural/epidermal border region ( $K$, arrow) and increased expression in the neural tube at stage 11 (L). (M-R) Expression of Fth 1 is initially ubiquitous ( $M$; stage $\left.4^{-}\right)$. Considerable variation is seen at stage 4, with some embryos expressing mainly outside the neural plate $(N)$ and others with low expression in non-neural ectoderm, higher in the neural plate and higher still in extraembryonic tissues (O; stage $\left.5^{-}\right)$. By stages 6-7 expression is seen more consistently in the neural plate (P). At later stages $(Q, R$, transverse sections through a stage 11 embryo), expression in the neural plate decreases slightly whereas the extraembryonic blood islands (bi) express very strongly. pnp, prospective neural plate; npb, neural plate border; ps, primitive streak; bi, blood islands. 
2003, Nakashima et al., 1993, Yang et al., 2002). We therefore used TUNEL staining to explore the distribution of apoptosis during normal development and in response to neural induction by a grafted node. TUNEL staining appears random until stage 4 (Fig. 2 A-G). From stage $4^{+}-5$ (Fig. $2 \mathrm{H}-\mathrm{K}$ ) apoptotic cells start to concentrate in an arc parallel to the anterior border of the neural plate, extending latero-caudally. As the embryo elongates and narrows (stages 5-14), the arc expands caudally, reminiscent of the early patterns of expression of BMP4 and BMP7 (Streit et al., 1998, Streit and Stern, 1999). From stages 8-9, TUNEL-positive cells are seen in the remnants of the primitive streak at the caudal tip of the axis (Fig. $2 \mathrm{~L}-\mathrm{N}$ ). The dorsal midline of the neural tube shows an increase in the number of TUNEL positive cells in regions where the neural folds are fusing (Fig. $2 \mathrm{M}-\mathrm{P}$ ). In addition, there are two regions of concentrated apoptosis, one in the rhombencephalon (Fig. $2 \mathrm{M}-\mathrm{P}$ ) which eventually becomes restricted to rhombomeres 3 and 5 (Graham et al., 1993, Jeffs et al., 1992) and another in the olfactory region at stages $9-14$ (Fig. 2 $\mathrm{N}-\mathrm{Q}$; see also Yang et al. (1998). At stage 13, apoptotic cells are seen at the edge of the anterior intestinal portal (Fig. 2Q) and anterior epidermis (Fig. 2 P, Q).

Hensey and Gautier also observed an arc of dying cells in Xenopus embryos at neurula stages and interpreted it as being within the neural plate (Hensey and Gautier, 1998). To determine more precisely the position of the arc in chick embryos, TUNEL staining was combined with in situ hybridization for neural plate
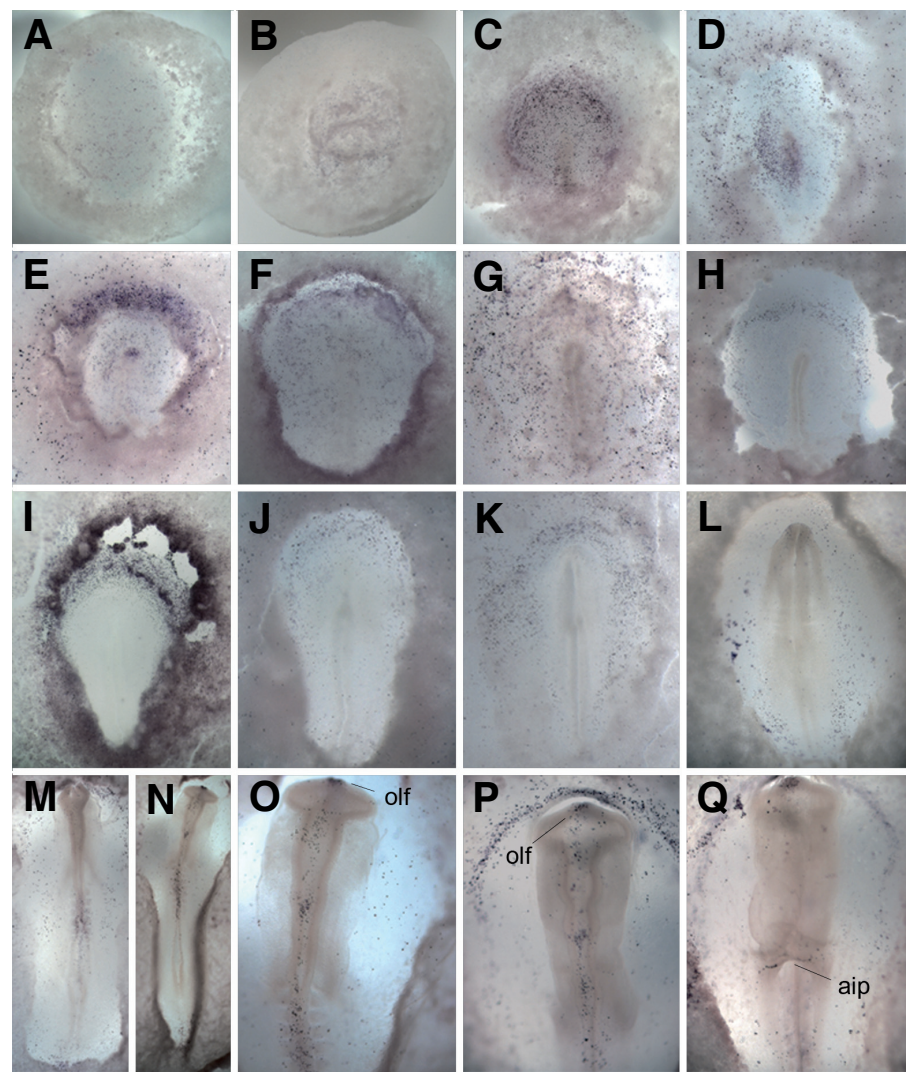

Fig. 2 (Left). Distribution of apoptosis revealed by TUNEL staining. (A-G) At early stages, TUNEL-positive cells are seen randomly scattered throughout the embryo (A, stage XII; $B$, stage XIII; $C$, stage $2^{+} ; D$, stage 3; E, stage $3^{+} ; F$, stage $4^{-} ; G$, stage 4). (H-L) From stage 4, PCD is more consistently concentrated in an arc at the neural/non-neural border and adjacent anterior non-neural ectoderm $\left(H\right.$, stage $4 ; \mathrm{I}$, stage $4^{+} ; \mathrm{J}$, stage $5^{-}$ $; K$, stage 5). In some embryos the arc of apoptotic cells extends far caudally at stages 6-8 (K and L, stage 8). (M-0) By early somite stages ( $M$, stage $8+; N$, stage 9, O, stage 10, P, Q stage 11 with $P$ viewed from dorsal side and $Q$ from ventral side). PCD is seen in the olfactory region (olf) at the anterior tip of the neural tube (N-Q), fusing neural folds (M-P) especially in the rhombencephalon and in the anterior intestinal portal endodermal region (Q). The arc of anterior epidermal dying cells is still seen at these stages (P). olf, olfactory region; aip, anterior intestinal portal.

Fig. 3 (Right). Comparison of regions of cell death with neural border and epidermal markers. TUNEL staining overlaps the region expressing the border markers DIx5 (A, D; stage $\left.4^{+}\right)$and Msx1 (B, C, E, F; stage 8). However the region of PCD also enters the prospective epidermis marked by Gata2 (G,J; stage 5) and Gata3 (H,I,K,L; stage 6). Each embryo is shown after initial in situ hybridization for the marker indicated, in blue (A-C, GI) and following TUNEL staining after in situ, in brown (D-F, J-L). In (E), note the double arc of TUNEL staining (arrowheads). An inner arc overlaps with Msx1 staining at the border of the neural plate, and there is also a more peripheral, epidermal arc.

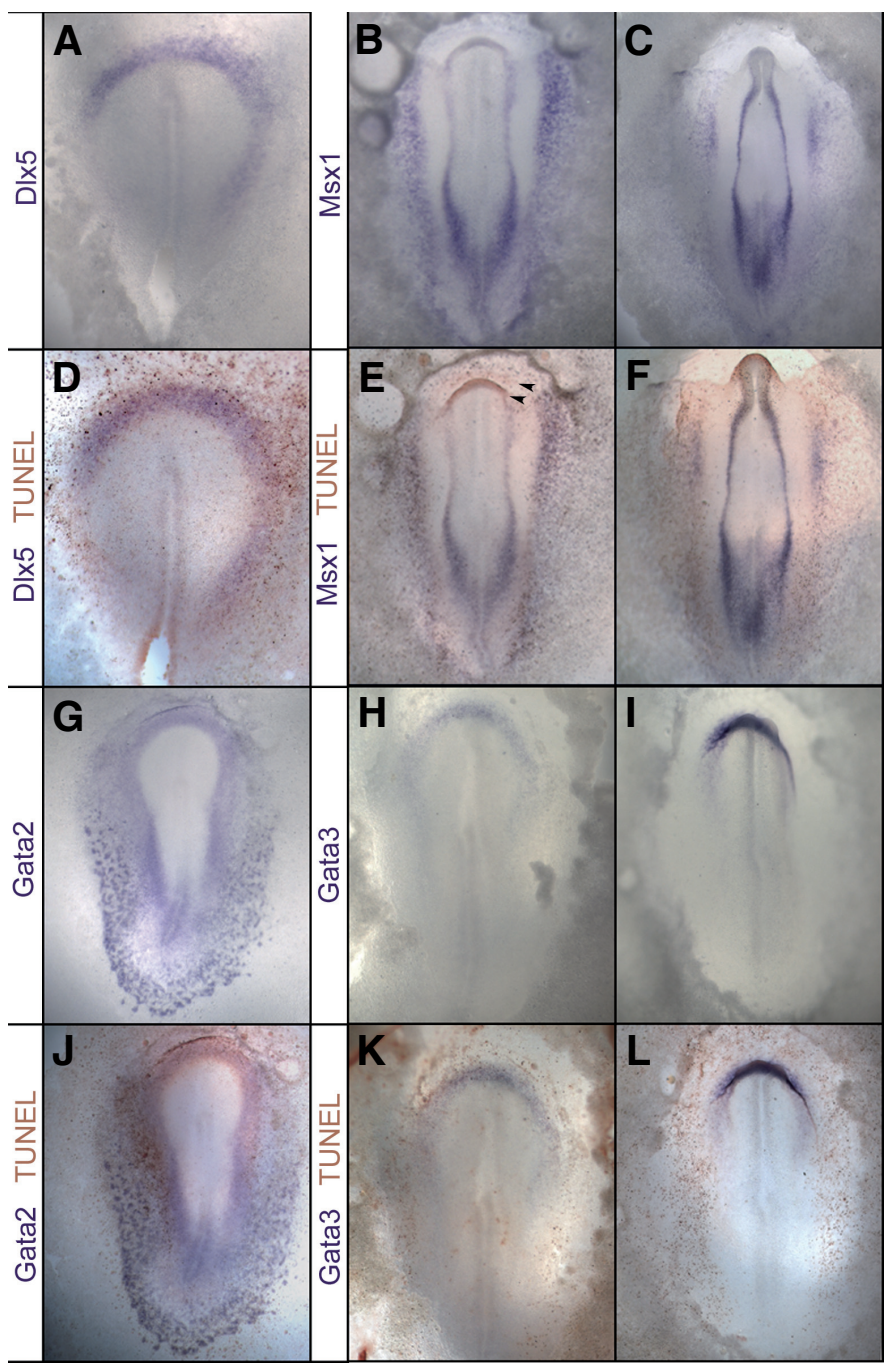



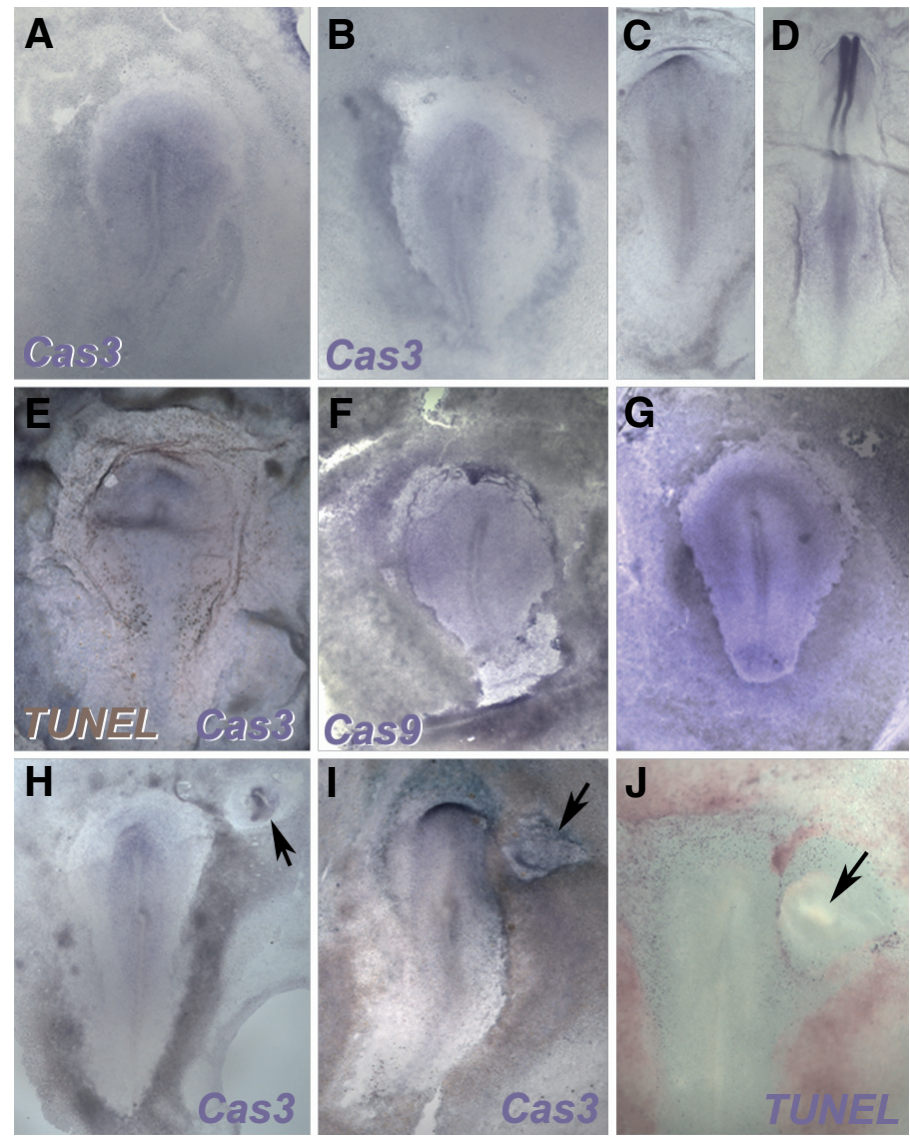

Fig. 4 (Above). Expression of caspases and responses to neural induction. (A-E) Expression of Caspase 3 at stage $4^{+}(A), 5(B), 6(C)$ and 8 (D). Panel (E) shows an embryo at stage 4- double-stained for Caspase3 (blue) and TUNEL (brown): apoptotic cells lie just beyond the edge of the Cas3-expressing domain, in the non-neural ectoderm. (F,G) Expression of Caspase 9 is widespread at stage $4^{+}$(F) but starts to clear from the neural plate and becomes concentrated at its border at stage 5 (G). (H-J) Responses to neural induction by a grafted node (arrows). The graft induces an initial domain of Caspase 3 expression $(H, I)$ similar to the pattern in the normal neural axis. TUNEL staining shows that the induced neural plate is devoid of apoptosis, which becomes concentrated as a sharp line between the induced and host neural plate (J). markers (Sox3 and Sox2; not shown), neural/epidermal border markers DIx5 and Msx1 (prospective neural crest and preplacodal regions; (McLarren et al., 2003) and early epidermal markers GATA2 and GATA3 (Sheng and Stern, 1999) (Fig. 3). Apoptotic cells can be seen both outside and inside of the neural-epidermal border, but at stage 5 the pattern is more concentrated in a region overlapping with the expression of the border markers Msx1 and DIx5 (Fig. 3 A-F) and extending into the epidermal (Gata2 and Gata3) domain (Fig. 3 G-L). Some embryos have two parallel arcs, one at the border of the neural plate and a second in the non-neural epidermis (e.g. Fig. 3E, arrowheads). Around stage 6-8, the arc at the border of the neural plate starts to disappear but the more distant arc in the non-neural ectoderm remains. As the neural plate elevates and starts to close (stages 8-10), the arc of PCD remains in the nonneural ectoderm (Fig. $2 \mathrm{P}, \mathrm{Q}$ ) whereas PCD at the neural plate border becomes confined to sub-regions of the neural folds (Fig. $2 \mathrm{M}-\mathrm{P}$ ) and prospective olfactory region (Fig. $2 \mathrm{~N}-\mathrm{Q}$ ). In conclusion, cell death is concentrated at the neural-epidermal border and proximal non-neural epidermis, especially in the head.

\section{Expression of Cas3 and Cas9 during early development}

Apoptotic death is controlled by the activity of specific caspases. To determine whether the localization of TUNEL staining corresponds to areas of high caspase expression, we first examined the expression of Caspase 3 (Cas3), the most downstream caspase in the cascade (Assefa et al., 2004, Faleiro et al., 1997, Li et al., 1997). No specific expression could be detected in any region before stage 3 (not shown). From stage 4, Cas3 starts to be expressed weakly in the central epiblast, primitive streak and early neural plate (Fig. 4 A-C) and eventually in the forming neural tube (Fig. 4D). This pattern differs from TUNEL staining at these stages, which is concentrated at the neural/epidermal border and epidermis (see above): double-staining for TUNEL and Cas3 reveals apoptosis abutting the edge of the Cas3-expressing domain (Fig. 4E).

Expression of the more upstream caspase Cas 9 was also examined (Srinivasula et al., 1998). It also starts weak and ubiquitous (Fig. 4F), but from stage 5 a region of slightly upregulated expression is seen surrounding the neural plate (Fig. 4G), not unlike the domain revealed by TUNEL staining
$1.5 \mathrm{~h}$

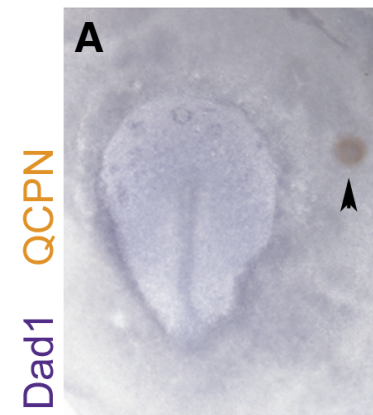

E
$3 \mathrm{~h}$

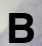

1

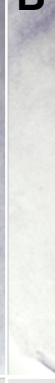

$\mathbf{F}$
$4 \mathrm{~h}$

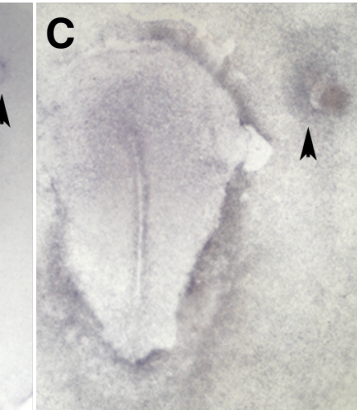

G
$5 \mathrm{~h}$

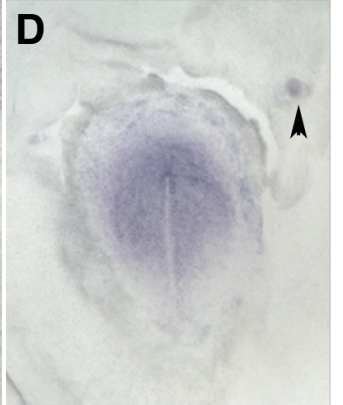

H

Fig. 5. Time course of induction of Dad1 by a graft of Hensen's node. Grafts of quail Hensen's nodes (arrowhead) into chick hosts (both donor and host at stage $3^{+}$) were analyzed at different time points following the transplant. No induction is seen after 1.5 hours $(A, E)$, weak induction begins at 3 hours $(B, F)$ and becomes more robust by 4-5 hours. $(\mathbf{E}, \mathbf{F})$ Sections through the grafted region of the embryos in (A-D), respectively, following in situ hybridization for Dad1 (purple) and staining with QCPN antibody to reveal the quail cells in the graft (brown). 

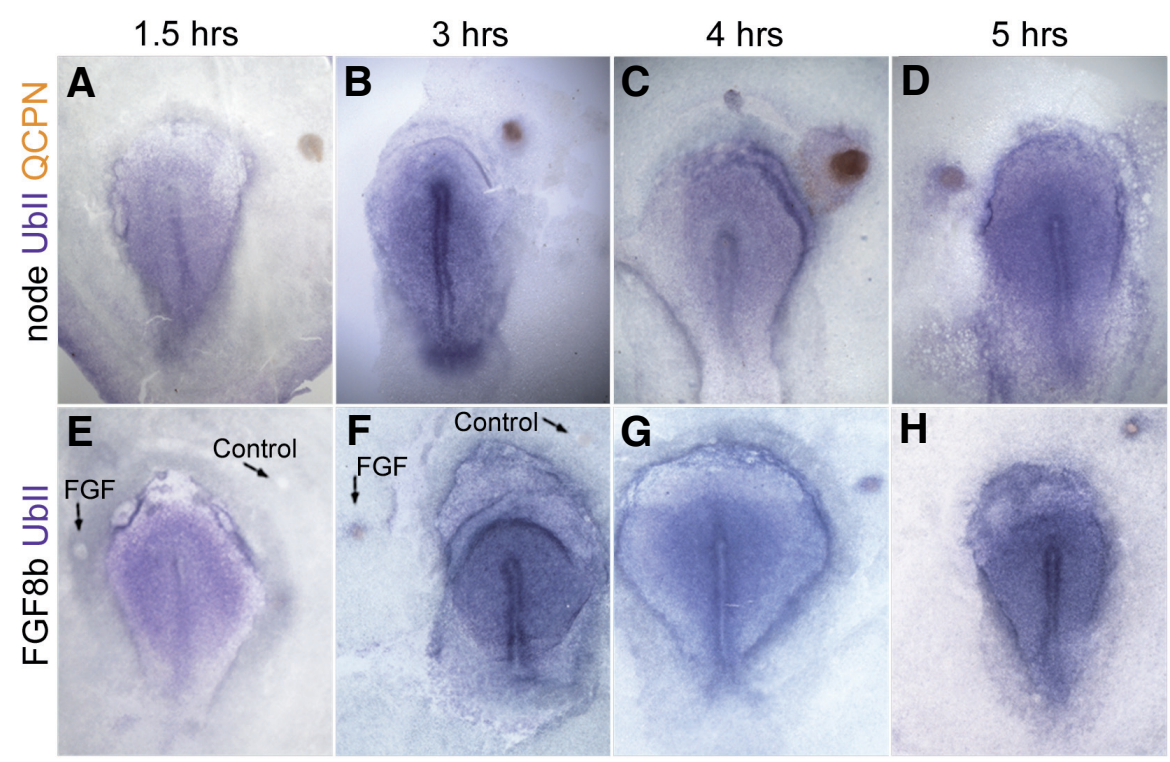

Fig. 6. Induction of Ubll by Hensen's node and by FGF8. Grafts of quail Hensen's nodes into chick hosts were analyzed at different time points following transplantation (A-D). Induction begins weakly at 3 hours and intensifies by 4-5 hours. A similar time-course of induction of Ub/l is seen following implants of FGF8soaked beads $(E-H)$.

node graft. Dad1 is faintly detectable in epiblast apposed to the node graft 3 hours after the transplant and induction becomes robust by 4 hours (Fig. 5). Ubll starts to be detected about 4 hours after grafting (Fig. 6 A-D). Induction of Ubll can be mimicked by a graft of FGF8soaked heparin bead (Fig. 6 E-H). We did not test the time course of induction of $F$ th because of its low level of expression in the extraembryonic epiblast.

\section{Effects of DAD1, UBII and FTH1 on PCD}

DAD1 was initially isolated as an antagonist
(Fig. 3). Thus, expression of Cas9 appears to correlate more closely with TUNEL staining than does Cas3.

\section{Neural induction is accompanied by downregulation of PCD}

Does neural induction by the organizer regulate PCD and Caspase expression? After overnight incubation following a node graft, both TUNEL staining and Cas 3 expression in the induced epiblast mirror those in the normal embryo (Fig. $4 \mathrm{H}-\mathrm{J}$ ). When the induced region is close to or overlaps with the arc of TUNEL staining of the normal embryo, apoptosis sharply decreases in the induced side. In some cases the TUNEL-positive domain is displaced away from the induced neural plate, forming a sharp border between the induced region and the host embryo (Fig. 4J). Despite some variability between embryos, the absence of apoptosis from the area surrounding the grafted node, with PCD becoming confined to the border of the induced neural plate and neighbouring epidermis, are consistent features of neural induction.

\section{Regulation of Dad1 and Ubll expression during neural induction}

The differential screen pointing to these genes was designed to identify factors induced within 5 hours of receiving signals from the organizer, Hensen's node. To determine how quickly this occurs, we analyzed the expression of Dad1 and Ub/l at different times following a

Fig. 7. Dad1 and apoptosis. (A-D) Comparison of Dad1 expression with TUNEL staining shows that apoptosis is concentrated to regions of the epiblast that are comparatively free of Dad1 expression at stages $4(A, B)$ and $5(C, D)$. (E-J) Dad1 weakly inhibits apoptosis. Embryos electroporated with either empty vector IRES-GFP $(E, H)$ or a mutated, inactive Dad1 construct $(G, J)$ show increased apoptosis (blue in E-G) around the electroporated region (circled in E-G, then revealed by anti-GFP staining in brown in $\mathrm{H}$-J). Embryos electroporated with wild-type Dad1 showa lower level of induced apoptosis in the electroporated non-neural ectoderm and neural plate border $(F, I)$. of cell death (Nakashima et al., 1993). Its expression in the forming neural plate, where it overlaps with Cas-3, suggests that it could function to prevent caspase-mediated cell death in this region. Consistent with this, Dad1 expression is complementary to TUNEL staining (Fig. 7 A-D). To determine whether Dad1 can limit cell death we compared electroporation of GFP, full-length

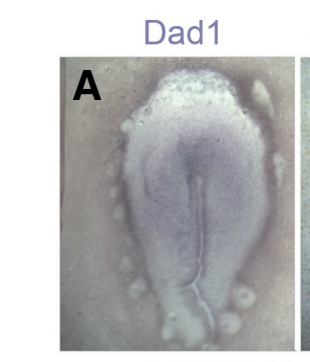

Dad1 TUNEL
Dad1
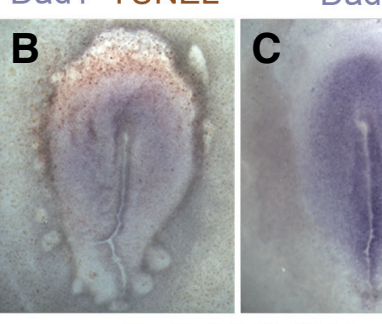

Dad1-IRES-GFP
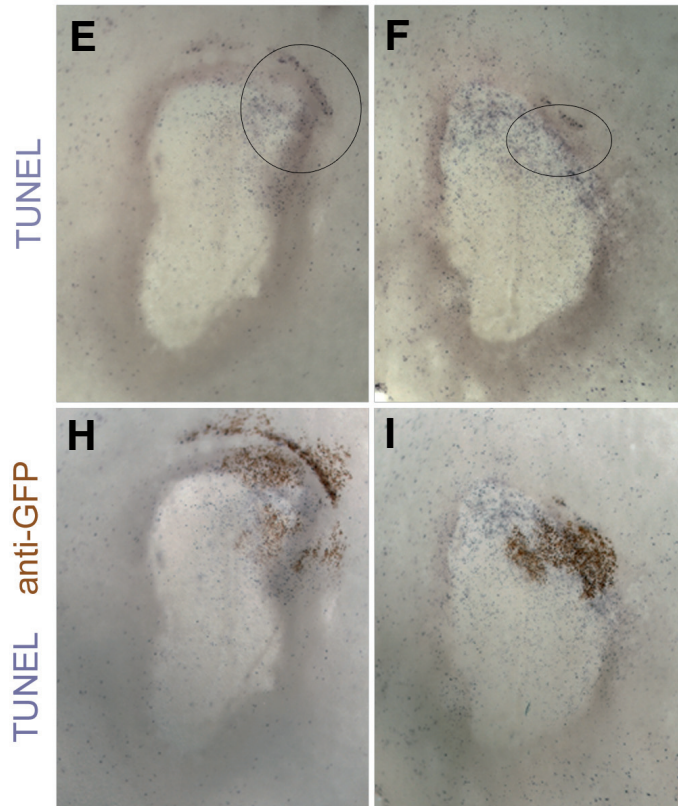

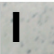

Dad1 TUNEL

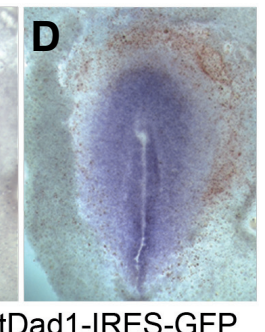

mtDad1-IRES-GFP
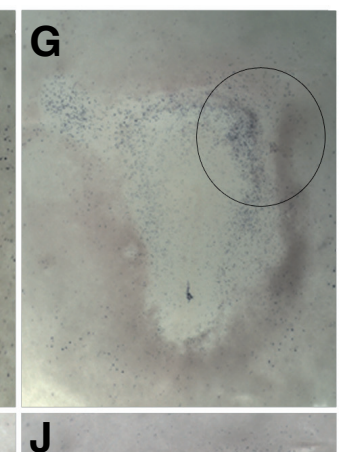

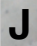


Dad1 and a truncated inhibitory form of DAD1 (Makishima et al., 2000). Electroporation itself slightly increases the incidence of apoptosis around the electroporated region. In some embryos (5/ 7 after 6 hours, 3/4 after overnight incubation) we observed a reduction of this induced apoptosis in Dad1-electroporated regions close to the border of the neural plate (e.g. Fig. $7 \mathrm{~F}, \mathrm{I}$ ), as compared to vector alone (Fig. $7 \mathrm{E}, \mathrm{H}$ ) or mutated-Dad1 (Fig. $7 \mathrm{G}$, J).

To test the role of FTH1 in apoptosis, we electroporated either full length fth 1 or a construct lacking the iron regulatory sequence (IRE) into primitive streak stage embryos. While no effect is observed 6 hours after electroporation (Fig. 8 A, D), after overnight culture the number of TUNEL-positive cells increases in embryos electroporated with Fth containing (in 9/10 embryos; Fig. $8 \mathrm{C}, \mathrm{F})$ and more strongly lacking the $\operatorname{IRE}(11 / 11$; Fig. $8 \mathrm{~B}, \mathrm{E})$. This effect is only detected in the ectoderm of the embryo proper and especially in the neuroectoderm, consistent with the idea that cell death is controlled by different mechanisms in different domains of the epiblast. This effect is not entirely cell autonomous, as it also affects some cells adjacent to those that received the construct during electroporation. No effect of $\mathrm{Ubll}$ was detected on the pattern or incidence of PCD (not shown).

Together, our results suggest that the early stages of neural induction are accompanied by regulation of PCD. Induction of an ectopic neural plate by a graft of Hensen's node is accompanied by an overall inhibition of cell death in the forming neural plate. The anti-apoptotic gene Dad1 is expressed in the nascent neural plate and induced by a graft of the organizer within 3 hours (as is

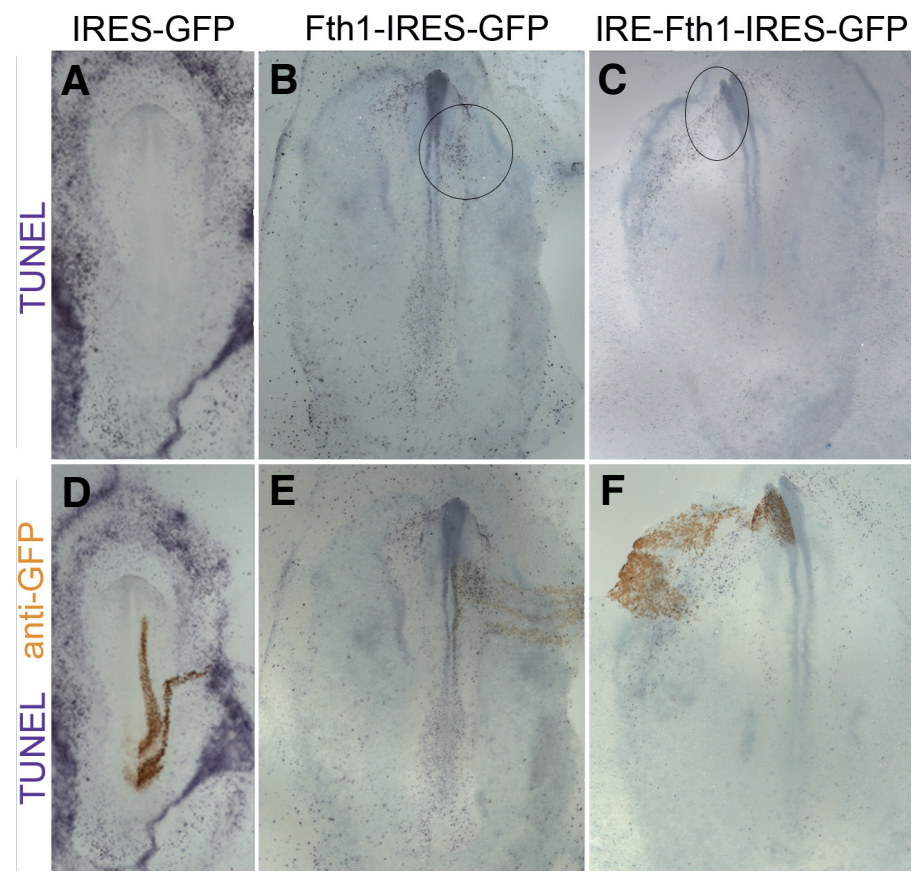

Fig. 8. Fth1 promotes apoptosis. Embryos electroporated with Fth1 containing $(C, F)$ or lacking $(B, E)$ its iron-regulatory element (IRE) show increased apoptosis in the electroporated region as compared to embryos electroporated with the empty vector IRES-GFP $(A, D)$. The same embryos are shown after initial TUNEL staining (in blue in $A-C$ ) and after subsequent staining for the electroporated cells with anti-GFP, (brown in D-F).
UblI), and Caspase 3 and Caspase9 are expressed in partly overlapping domains, with a border in the region where PCD becomes concentrated (the edge of the neural plate and adjacent epidermis). However Dad1, Ubll and Fth appear to be dispensable during early neural plate development.

\section{Discussion}

\section{Dad1 as anti-apoptotic factor}

Defender Against Cell Death (Dad1) was first identified as a gene responsible for apoptotic cell death in temperature-sensitive mutants (tsBN7) of the hamster BHK21 cell line (Nakashima et al., 1993). Since then, homologues have been identified in many species including human (Nakashima et al., 1993), mouse (Makishima et al., 1997), Xenopus and nematode (Sugimoto et al., 1995), Arabidopsis and rice (Gallois et al., 1997, Makishima et al., 1997), all of which can rescue the tsBN7 mutation. DAD1 is an effective anti-apoptotic protein but cannot protect against all apoptotic events: ectopic expression of human or nematode DAD1 prevents over $20 \%$ of PCD that would otherwise take place during normal embryogenesis in $C$. elegans (Sugimoto et al., 1995)

Dad1 encodes the $\mu$-subunit of the oligosaccharyltransferase complex OST (Kelleher and Gilmore, 1997, Makishima et al., 1997, Silberstein et al., 1995) but the exact mechanism by which it regulates apoptosis is not known. DAD1 binds to the antiapoptotic protein $\mathrm{MCL}-1$; however a mutant version still able to interact in this way but lacking the C-terminal 4 amino acids disrupts $\mathrm{N}$-linked glycosylation and prevents rescue of the tsBN7 mutation (Makishima et al., 2000, Yoshimi et al., 2000); fusion of GFP at the C-terminus also disrupts DAD1 function (Nikonov et al., 2002).

Apart from the finding that DAD1 mutant mice die from excess apoptosis in the ectoderm and the distal tip of the primitive streak (Hong et al., 2000), there has been no indication for a role of DAD1 in early development. Here we report that Dad1 expression is induced as a very early response to signals from the organizer, Hensen's node, during neural induction. Its normal expression in the neural plate of the early embryo corresponds to a region where the incidence of apoptosis is particularly low. As the neural plate arises, TUNEL-positive cells accumulate at the edge of the Dad1-expressing domain, forming an arc at the border of the neural plate (future neural crest and placode area) and proximal non-neural ectoderm. These regions retain a higher incidence of apoptosis at later stages of development (Graham et al., 1993, Hensey and Gautier, 1998, Jeffs et al., 1992, Sanders et al., 1997a, Sanders et al., 1997b, Wride et al., 1994). In our experiments, misexpression of DAD1 at the edges of the neural plate causes a small reduction in the incidence of PCD compared to electroporated controls in some embryos, but this is quite variable. Consistent with this variability, we did not detect any effect of loss-of-function (using either a dominant-negative version of Dad1 or antisense morpholinos) on cell death (not shown). A possible explanation is that the electroporation is done too late to eliminate all DAD1 protein from the cells. This is likely because in normal embryos Dad1 is expressed ubiquitously at low levels, and it has also been reported that 6 hours are necessary for complete turnover of intracellular DAD1 protein when its synthesis is prevented (Makishima et al., 2000). This suggests that for DAD1 
levels to be lowered sufficiently it may be necessary to introduce the morpholino or inhibitory construct at a much earlier stage.

\section{Ubll and apoptosis}

Ubiquitin was identified as a 74 amino acid polypeptide involved in lymphocyte differentiation, with homologs in virtually all organisms including plants (Goldstein et al., 1975). Ubiquitin is considered to be the most conserved protein known: for example, yeast ubiquitin differs from those of animals by only 3 amino acids (Ozkaynak et al., 1984). Typically, ubiquitins are found in the genome as polyubiquitins (Hunt and Dayhoff, 1977, Ozkaynak et al., 1984), encoding repeats of the 76 amino acid Ubiquitin monomer. Ubiquitins can be added to other proteins. "Ubiquitination" refers to processes leading to selective targeting and degradation by the ubiquitin-proteasome system, while "ubiquitinylation" describes non-turnover-related post-translational modifications (Emre and Berger, 2004, Haglund and Dikic, 2005, Huang and D'Andrea, 2006, Staub and Rotin, 2006).

Links between apoptosis and polyubiquitin were established in insects (Haas et al., 1995, Schwartz et al., 1990) and later extended to vertebrates (reviewed in Lee and Peter, 2003). Of particular interest in the context of neural induction is the discovery of tight links between caspase activity, the cell death effector IAP, ubiquitination and NF- $\mathrm{KB}$ signalling, an upstream regulator of BMP (Gyrd-Hansen et al., 2008, Paquette et al., 2010, Tokunaga et al., 2009). However, we cound not detect changes in cell death after misexpression of Ubll, suggesting that it is not sufficient either to induce or to inhibit PCD at these stages of development. Upregulation of $\mathrm{Ubll}$ as an early response to signals from the organizer, which we detect after only 3 hours of exposure to signals from Hensen's node, may serve functions unrelated to the regulation of apoptosis, although we could also not detect any effect of Ubll misexpression on expression of various cell type markers.

\section{FTH1 and apoptosis}

Iron is crucial but also potentially toxic to cells. Ferritins play a critical role in iron sequestration (Torti and Torti, 2002). Two main types of ferritins exist in animals: heavy (FTH) and light chain, encoded by different genes of common origin (Harrison and Adams, 2002, Harrison et al., 1998). The chicken genome contains a single fth1 gene (see also Stevens et al., 1987). FTH1 plays an important role in the regulation of iron homeostasis (Theil, 2003): in vertebrates, the heavy chain is responsible for accelerated oxidation of toxic $\mathrm{Fe}$ (II) to $\mathrm{Fe}(\mathrm{III})$, which is less toxic to cells (Levi et al., 1989a, Levi et al., 1989b, Quintana et al., 2004). Ferritin is important from early stages of development: $\mathrm{Fth}^{(--)}$mutant mice die between E3.5-E9.5 (Ferreira et al., 2000).

fth 1 is regulated both transcriptionally and post-transcriptionally; similar levels of mRNA can result in a 10-fold difference in protein levels (Stevens et al., 1987, Zahringer et al., 1975). This regulation involves interaction between a conserved 28 bp Iron Regulatory Element (IRE) sequence in the 5' UTR and Iron Regulatory Proteins (IRPs) 1 and 2 (Eisenstein, 2000, Harrell et al., 1991, Kim et al., 1995, Theil, 1990, Thomson et al., 1999), which repress $\mathrm{FTH} 1$ translation in low iron conditions.

FTH1 can have both pro- and anti-apoptotic functions. Cytoplasmic FTH1 can protect hepatocytes and endothelial cells against some apoptotic inducers (Cairo et al., 1995, Theil, 1987).
Upregulation of FTH during B-lymphocyte differentiation reduces free iron levels and also increases resistance to oxidative damage (Cozzi et al., 2000, Epsztejn et al., 1999), whilst down-regulation increases free iron and is associated with increased apoptosis (Yang et al., 2002).

Our experiments reveal a slight increase in the incidence of PCD following overexpression of Fth1, consistent with a proapoptotic function of FTH1 in the early epiblast. An early response to neural inducing signals appears to include upregulation of Fth1, which may promote PCD in the vicinity of the neural plate, especially in regions that are free from Dad1, which is also induced by signals from the node.

\section{Cell death during neural induction}

PCD was originally envisaged as a process of elimination of embryonic cells for "phylogenetic, histogenetic and morphogenetic" purposes (Glucksmann, 1951). There have been numerous studies on the role of apoptosis during many aspects of development, including patterning the early neural crest (Graham et al., 1994, Graham et al., 1993, Homma et al., 1994, Jeffs et al., 1992, Jeffs and Osmond, 1992, Lawson et al., 1999, Wakamatsu et al., 1998). The patterns of PCD reported here confirm an earlier report in the chick, including variability in staining patterns, increased apoptosis at the tip of the streak and left-right asymmetric patterns in a subset of embryos (Sanders et al., 1997b). However we did not observe the increased PCD in the posterior marginal zone and Koller's sickle in pre-primitive streak stage embryos described by others (Hirata and Hall, 2000), and only 6 out of more than 60 embryos analyzed at stages 8-14 showed increased PCD in the notochord as previously reported (Hirata and Hall, 2000).

Previous studies in Xenopus (Hensey and Gautier, 1998, Yeo and Gautier, 2003) obtained results reminiscent of those described here, except that they observed high cell death in the neuroectoderm. Our study and another (Sanders et al., 1997b) suggest instead that the chick neural plate is an area of decreased or even absent PCD. At later stages of Xenopus development, increased PCD is seen in stripes of primary neurons, sensory placodes and spinal cord (Hensey and Gautier, 1998). There is variability even at stages when the patterns of PCD in the chick become consistent: for example only $67 \%$ of Xenopus embryos at neural plate stages (stage 13) and 52\% of embryos at stage 37 contained more than 5 TUNEL cells per embryo (Hensey and Gautier, 1998). Hensey and Gautier proposed that PCD may contribute to sharpen the boundaries between neural and nonneural territories. Our finding that cells undergoing apoptosis become progressively concentrated at the neural/non-neural border are consistent with this hypothesis.

Several secreted factors have been implicated in the regulation of cell death, especially members of the BMP family. BMP4 is an effector for the localization of apoptosis to rhombomeres 3 and 5 (Graham et al., 1994). Indeed, the lateral neural plate and its descendants, dorsal neural tube and neural crest teritory, express a number of BMP family members strongly (Liem et al., 1997, Liem et al., 1995).

In zebrafish, the only data on early PCD concern earlier (Negron and Lockshin, 2004, Yabu et al., 2001) or later (Cole and Ross, 2001) stages of development; for the stages at which it has been studied, the results correspond closely to ours in the chick. 
Interestingly lower vertebrates and non-vertebrate chordates do not undergo apoptosis prior to the mid-blastula transition (zebrafish: Ikegami et al., 1999, Negron and Lockshin, 2004; Xenopus: Hensey and Gautier, 1997; sea urchin: Voronina and Wessel, 2001), suggesting that transcription is required to control embryonic cell death.

During zebrafish gastrulation, cells undergoing apoptosis have only very low levels of active caspase3, despite Cas3 being present in the pool of maternal factors as well as being expressed during gastrulation and later in development (Negron and Lockshin, 2004, Yabu et al., 2001). The patterns of Cas3 expression in zebrafish are comparable to those we report in early chick development (Yabu et al., 2001). Thus, these patterns appear to have been conserved during vertebrate evolution.

We find that the expression patterns of Cas9 and Cas 3 overlap significantly; Cas9 is expressed more ubiquitously but at low levels. However there is a region of increased Cas9 expression that surrounds the prospective neural plate and which seems to correspond to the main sites of cells undergoing PCD. Dad1 appears to be located within this domain, raising the possibility that Dad1 may contribute to protect cells against apoptosis within the newly induced neural plate, while a narrow region expressing Cas 3 and Cas9 but devoid of Dad1 ensures that PCD becomes restricted to the edge of the neural plate (prospective neural crest and placode territory). However we were unable to test this directly using loss-of-function experiments.

\section{Conclusions}

Together, our results reveal that neural induction by the organizer (Hensen's node) and normal neural plate development are accompanied by a decrease in the incidence of PCD in the neural plate and an increase in apoptosis at the neural plate border and proximal anterior non-neural ectoderm. This correlates with the induction of Dad1 expression in the prospective neural plate and the distribution of Fth 1 and Caspases in adjacent regions. Proand anti-apoptotic genes are induced as early responses to signals from Hensen's node. While Dad1 may have weak antiapoptotic properties and Fth1 seems to promote PCD, none of these genes appears to influence cell identity at these stages of development or to be required for early neural plate development.

\section{Materials and Methods}

\section{Eggs and embryos}

Fertilized Brown Bovan Gold hens' eggs were obtained from Henry Stewart \& Co. Fertilized quails' eggs were obtained from B.C. Potter Rosedean farm. Eggs were incubated at $38^{\circ} \mathrm{C}$ and staged according to Hamburger and Hamilton (1951). A modified version of the New technique was used to culture embryos (Stern and Ireland, 1981). Transplantation of Hensen's node was performed at stage $3+/ 4$ as described previously (Stern, 1999, Storey et al., 1992). The graft was placed in the inner $1 / 3$ of the area opaca at or above the level of the host node (Streit et al., 1997). Following transplantation, cultured embryos were incubated at $38^{\circ} \mathrm{C}$ in a humid chamber to the required stage.

\section{In situ hybridization}

Whole-mount in situ hybridization with digoxigenin- (DIG) or fluorescein-labelled riboprobes was used, as previously described (Stern, 1998, Streit and Stern, 2001). For in situ hybridization with two probes, one probe was detected using Nitro Blue Tetrazolium (NBT) and BromoChloro-Indole-Phosphate (BCIP) as alkaline-phosphatase substrates to yield a deep purple colour. The other probe was detected using BCIP alone to give a light blue colour. In some cases lodophenyl-NitrophenylPhenyl-Tetrazolium Chloride (INT)-BCIP was used as an alternative to the latter to give a brick-red colour. The chromogens (Roche) were diluted in $100 \mathrm{mM}$ Tris-Buffered saline $(\mathrm{pH} 9.5)$ containing $50 \mathrm{mM} \mathrm{Mg}^{++}$and $1 \%$ Tween-20 (NTMT): $4.5 \mu \mathrm{l} \mathrm{NBT} \mathrm{stock}(75 \mu \mathrm{g} / \mathrm{ml}$ in $70 \%$ dimethylformamide, DMF), $3.5 \mu \mathrm{l} \mathrm{BCIP} \mathrm{stock}(50 \mathrm{mg} / \mathrm{ml}$ in $100 \%$ DMF) per $1.5 \mathrm{ml}$ for dark purple, $7.5 \mu$ l BCIP stock: $(50 \mathrm{mg} / \mathrm{ml}$ in $100 \%$ DMF) per $\mathrm{ml}$ for light blue or 7.5 $\mu$ I INT-BCIP per $\mathrm{ml}$ for brick-red colour.

Dad1 and fth1 were cloned into pBlueScript. To generate antisense riboprobes, the plasmids were digested with $\mathrm{Xhol}$ and transcribed with $\mathrm{T} 3$ Polymerase in both cases. Cas3 and Cas 9 cDNA (both in pGEMTeasy) were linearised with $\mathrm{Ncol}$ and transcribed with SP6.

To distinguish between the almost identical sequences of Ubl and Ubll, antisense riboprobes were designed to incorporate 3' UTR sequence, which differs between for these genes. The fragments were isolated by PCR from a mixture of two cDNA libraries (stage 2-4 and stages 18-20). The following primers were used: Ubl:

Forward: ACTACAACATCCAGAAG; Reverse: ATGTGCAACAGAAAAACT.

Ubll:

Forward: CCTGTCTGACTACAACATC; Reverse: GGATGCAAGAACTTTATTG.

PCR fragments were extracted, cloned into pGEM T-easy and transformed into competent bacteria (Promega). After sequencing to validate the clones and to determine the orientation of the insert, they were digested with $\mathrm{Ncol}$ and transcribed with SP6.

\section{Whole mount immunohistochemistry}

Whole-mount immunohistochemistry was carried out as previously described (Stern, 1998, Streit and Stern, 2001). GFP was detected with rabbit anti-GFP (Molecular Probes) (1:2,500 in blocking buffer), followed by goat anti-rabbit-HRP (Santa Cruz) $(1: 2,500)$. Quail cells were detected with monoclonal antibody QCPN (quail cell perinuclear antigen) (developed by Dr B.M. Carlson and obtained from the Developmental Studies Hybridoma Bank, maintained by the Department of Pharmacology and Molecular Sciences, The John Hopkins University School of Medicine, Baltimore, MD 21205, under contract N01-HD-2-3144 from NICHD) as previously described (Storey et al., 1992) using anti-mouse IgG-HRP (Jackson; 1:2,500). FTH1 protein was detected using affinity-purified, rabbit anti-human FTH1 antibody (FERH13-A, Alpha Diagnostic; 1:250). This was raised against a 15aa peptide near the amino-terminus of FTH1, which is $100 \%$ conserved in mouse, rat, human, bovine monkey and chicken FTH1. This was detected using goat anti-rabbit-HRP (Santa Cruz; 1:2,500). The HRP-activity was revealed using 3,3'-diaminobenzidine (DAB) and $\mathrm{H}_{2} \mathrm{O}_{2}$ as previously described (Stern, 1998).

\section{Terminal deoxynucleotidyl transferase mediated nick-end labelling (TUNEL)}

The TUNEL method was modified from published protocols (Gavrieli et al., 1992, Wijsman et al., 1993). Embryos were fixed as for in situ hybridization, stored in methanol at $-20^{\circ} \mathrm{C}$ and rehydrated gradually to PBT. Embryos were placed in TdT buffer (30 mM Tris pH 7.4,100 mM Na cacodylate, $1 \mathrm{mM} \mathrm{CoCl}_{2}$ ) for $30 \mathrm{~min}$ with gentle rocking. The buffer was replaced with $400 \mu \mathrm{l}$ of TdT reaction mix (TdT buffer, $0.5 \mu \mathrm{I}$ DIG-dUTP, 2 $\mu$ l terminal transferase; Roche) for $4 \mathrm{~h}$ at room temperature. After washing in TBST, alkaline-phosphatase conjugated anti-DIG antibody $(1: 5,000)$ staining was performed as for in situ hybridization.

\section{Wax embedding and sectioning}

Stained embryos were rinsed in PBS and dehydrated with alcohol washes (5 minutes in 100\% methanol and $10 \mathrm{~min}$ in 100\% propan-2-ol). 
They were then cleared in tetrahydronaphthalene for $30 \mathrm{~min}$, embedded in Fibrowax, sectioned at $8 \mu \mathrm{m}$ and mounted on gelatin-albumen-coated glass slides. After drying, they were de-waxed using Histoclear and mounted in Canada Balsam.

\section{Constructs for electroporation}

Misexpression experiments were performed by electroporation using the $\mathrm{pCA} \beta$ vector ( $\leq$-actin promoter, IRES, GFP, with the gene of interest inserted upstream of the IRES). To generate Dad1 constructs, the vector was digested with $\mathrm{BsmBI}$ and Clal and gel-purified using a Gel Extraction Kit (Qiagen). The reading frame of chick Dad1 was amplified by PCR from two chick cDNA libraries (stage 2-4 and 18-20, respectively). Primers (Forward: GATCAGCGGCCGCATGTCGGGCACGGCGGG; Reverse: TGCTCATCGATTCAGCCAACAAAATTGATA) incorporating Notl and Clal sites (underlined above). Ligation was then performed using T4 ligase (Promega) and verified by sequencing. A mutated version of Dad1 lacking the C-terminal 6 aminoacids (VINFVG) was constructed using the same forward primer and reverse primer TGCTCATCGATTCAGACGAGATGCAGGATGGT, containing a Clal site).

Ubll constructs were generated as for Dad1, using primers: GATCAGCGGCCGCGACCAACATGCAGATCTTC (forward) and TGCTAATCGATTCTTCAGTTACCACCCCTG (reverse). For Fth1, the primers used were: GATCAGCGGCCGCGATTGGGACGGAACCGGC (forward) and TGCTCATCGATGCCTTCAGCTGTCACTTTCCCCG (reverse). An additional construct, lacking the Iron Regulatory Element (IRE) present in the 5' UTR of fth1, the ORF of fth1 lacking 5' UTR sequences was amplified using primers:

GATCAGCGGCCGCGCCATGGCTACGCCTCC (forward) and TGCTCATCGATGCCTTCAGCTGTCACTTTCCCCG (reverse).

\section{Electroporation}

In vivo electroporation (Muramatsu et al., 1997), modified for early embryos (Voiculescu et al., 2007, Voiculescu et al., 2008) was used to introduce the expression constructs described above or fluoresceinlabelled morpholinos into selected cells in living whole embryos at stage $3+/ 4$. Three or four $50 \mathrm{msec}$ pulses (500 msec apart) of 5.5-6 Volts were given with a TSS20 pulse generator (Intracel). Following electroporation, embryos were placed onto a vitelline membrane and grown to the desired stage at $38^{\circ} \mathrm{C}$. The electroporated embryos were grown for between 6-24 hours and then processed for in situ hybridization with various markers including Sox3, Sox2 (Rex et al., 1997, Uwanogho et al., 1995), ERNI (Streit et al., 2000), DIx5 (McLarren et al., 2003, Streit and Stern, 1999, Yang et al., 1998), Pax7 (McLarren et al., 2003) and Gata2 (Sheng and Stern, 1999). After in situ hybridization, antibody staining against GFP was used to reveal the electroporated cells.

\section{Design of morpholinos}

The chick Dad1 sequence (GenBank U83627) was confirmed by sequencing a fragment of genomic DNA containing the Dad1 gene. A fluorescein-tagged morpholino (CACCCGAACCCGCCGTGCCCGACAT) targeting the first 25 bases of the coding sequence was designed by Gene Tools. A fluorescein-labelled control morpholino (sequence CCTCTTACCTCAgTTACAATTTATA) (Gene Tools) was used as a negative control. Each morpholino was used at $2 \mathrm{mM}$ in water containing $0.01 \%$ Fast Green and $6 \%$ sucrose, mixed with empty pCA $\beta$ at a final dilution of $1 \mu \mathrm{g} / \mu \mathrm{l}$ (used as a carrier and as an additional marker for the electroporated cells) was introduced into cells by electroporation as described (Sheng et al., 2003, Voiculescu et al., 2007, Voiculescu et al., 2008).

\section{Acknowledgements}

This study was funded by grants from the Medical Research Council and the National Institutes of Health (R01 MH60156). Anna Gibson was funded by a PhD studentship from BBSRC. We are grateful to Ms Sharon Boast for technical assistance.

\section{References}

ASSEFA, Z., BULTYNCK, G., SZLUFCIK, K., NADIF KASRI, N., VERMASSEN, E., GORIS, J., MISSIAEN, L., CALLEWAERT, G., PARYS, J.B. and DE SMEDT, H. (2004). Caspase-3-induced truncation of type 1 inositol trisphosphate receptor accelerates apoptotic cell death and induces inositol trisphosphate-independent calcium release during apoptosis. J Biol Chem 279: 43227-43236.

CAIRO, G., TACCHINI, L., POGLIAGHI, G., ANZON, E., TOMASI, A. and BERNELLIZAZZERA, A. (1995). Induction of ferritin synthesis by oxidative stress. Transcriptional and post-transcriptional regulation by expansion of the «free» iron pool. J Biol Chem 270: 700-703.

COLE, L.K. and ROSS, L.S. (2001). Apoptosis in the developing zebrafish embryo. Dev Biol 240: 123-142.

COZZI, A., CORSI, B., LEVI, S., SANTAMBROGIO, P., ALBERTINI, A. and AROSIO, P. (2000). Overexpression of wild type and mutated human ferritin $\mathrm{H}$ chain in HeLa cells: in vivo role of ferritin ferroxidase activity. J Biol Chem 275: 25122-25129.

DE ALMEIDA, I., ROLO, A., BATUT, J., HILL, C., STERN, C.D. and LINKER, C. (2008). Unexpected activities of Smad7 in Xenopus mesodermal and neural induction. Mech Dev 125: 421-431.

EISENSTEIN, R.S. (2000). Iron regulatory proteins and the molecular control of mammalian iron metabolism. Annu Rev Nutr 20: 627-662.

EMRE, N.C. and BERGER, S.L. (2004). Histone H2B ubiquitylation and deubiquitylation in genomic regulation. Cold Spring Harb Symp Quant Biol 69: 289-299.

EPSZTEJN, S., GLICKSTEIN, H., PICARD, V., SLOTKI, I.N., BREUER, W. BEAUMONT, C. and CABANTCHIK, Z.I. (1999). H-ferritin subunit overexpression in erythroid cells reduces the oxidative stress response and induces multidrug resistance properties. Blood 94: 3593-3603.

FALEIRO, L., KOBAYASHI, R., FEARNHEAD, H. and LAZEBNIK, Y. (1997) Multiple species of CPP32 and Mch2 are the major active caspases present in apoptotic cells. EMBO J 16: 2271-2281.

FERREIRA, C., BUCCHINI, D., MARTIN, M.E., LEVI, S., AROSIO, P. GRANDCHAMP, B. and BEAUMONT, C. (2000). Early embryonic lethality of $\mathrm{H}$ ferritin gene deletion in mice. $J$ Biol Chem 275: 3021-3024.

GALLOIS, P., MAKISHIMA, T., HECHT, V., DESPRES, B., LAUDIE, M., NISHIMOTO T. and COOKE, R. (1997). An Arabidopsis thaliana cDNA complementing a hamster apoptosis suppressor mutant. Plant $J$ 11: 1325-1331.

GAVRIELI, Y., SHERMAN, Y. and BEN-SASSON, S.A. (1992). Identification of programmed cell death in situ via specific labeling of nuclear DNA fragmentation. J Cell Biol 119: 493-501.

GLUCKSMANN, A. (1951). Cell deaths in normal vertebrate ontogeny. Biol Rev26: 59-86.

GOLDSTEIN, G., SCHEID, M., HAMMERLING, U., SCHLESINGER, D.H., NIALL, H.D. and BOYSE, E.A. (1975). Isolation of a polypeptide that has lymphocytedifferentiating properties and is probably represented universally in living cells. Proc Natl Acad Sci USA 72: 11-15.

GRAHAM, A., FRANCIS-WEST, P., BRICKELL, P. and LUMSDEN, A. (1994). The signalling molecule BMP4 mediates apoptosis in the rhombencephalic neural crest. Nature 372: 684-686

GRAHAM, A., HEYMAN, I. and LUMSDEN, A. (1993). Even-numbered rhombomeres control the apoptotic elimination of neural crest cells from odd-numbered rhombomeres in the chick hindbrain. Development 119: 233-245.

GYRD-HANSEN, M., DARDING, M., MIASARI, M., SANTORO, M.M., ZENDER, L., XUE, W., TENEV, T., DA FONSECA, P.C., ZVELEBIL, M., BUJNICKI, J.M. et al. (2008). IAPs contain an evolutionarily conserved ubiquitin-binding domain that regulates NF-kappaB as well as cell survival and oncogenesis. Nat Cell Biol 10: 1309-1317.

HAAS, A.L., BABOSHINA, O., WILLIAMS, B. and SCHWARTZ, L.M. (1995). Coordinated induction of the ubiquitin conjugation pathway accompanies the developmentally programmed death of insect skeletal muscle. J Biol Chem270: 9407-9412.

HAGLUND, K. and DIKIC, I. (2005). Ubiquitylation and cell signaling. EMBO J 24 3353-3359.

HAMBURGER, V. and HAMILTON, H.L. (1951). A series of normal stages in the 
development of the chick embryo. J Morphol 88: 49-92.

HARLAND, R. (2000). Neural induction. Curr Opin Genet Dev 10: 357-362.

HARRELL, C.M., MCKENZIE, A.R., PATINO, M.M., WALDEN, W.E. and THEIL, E.C. (1991). Ferritin mRNA: interactions of iron regulatory element with translational regulator protein $\mathrm{P}-90$ and the effect on base-paired flanking regions. Proc Natl Acad Sci USA 88: 4166-4170.

HARRISON, H. and ADAMS, P.C. (2002). Hemochromatosis. Common genes, uncommon illness? Can Fam Physician 48: 1326-1333.

HARRISON, P.M., HEMPSTEAD, P.D., ARTYMIUK, P.J. and ANDREWS, S.C. (1998). Structure-function relationships in the ferritins. Met lons Biol Syst 35: 435-477.

HEMMATI-BRIVANLOU, A. and MELTON, D. (1997). Vertebrate embryonic cells will become nerve cells unless told otherwise. Cell 88: 13-17.

HENSEY, C. and GAUTIER, J. (1997). A developmental timer that regulates apoptosis at the onset of gastrulation. Mech Dev 69: 183-195.

HENSEY, C. and GAUTIER, J. (1998). Programmed cell death during Xenopus development: a spatio-temporal analysis. Dev Biol 203: 36-48.

HIRATA, M. and HALL, B.K. (2000). Temporospatial patterns of apoptosis in chick embryos during the morphogenetic period of development. Int J Dev Biol 44: 757-768.

HOMMA, S., YAGINUMA, H. and OPPENHEIM, R.W. (1994). Programmed cell death during the earliest stages of spinal cord development in the chick embryo: a possible means of early phenotypic selection. J Comp Neurol 345: 377-395.

HONG, N.A., FLANNERY, M., HSIEH, S.N., CADO, D., PEDERSEN, R. and WINOTO, A. (2000). Mice lacking Dad1, the defender against apoptotic death1 , express abnormal $\mathrm{N}$-linked glycoproteins and undergo increased embryonic apoptosis. Dev Biol 220: 76-84.

HUANG, T.T. and D'ANDREA, A.D. (2006). Regulation of DNA repair by ubiquitylation. Nat Rev Mol Cell Biol 7: 323-334.

HUNT, L.T. and DAYHOFF, M.O. (1977). Amino-terminal sequence identity of ubiquitin and the nonhistone component of nuclear protein A24. Biochem Biophys Res Commun 74: 650-655.

IKEGAMI, R., HUNTER, P. and YAGER, T.D. (1999). Developmental activation of the capability to undergo checkpoint-induced apoptosis in the early zebrafish embryo. Dev Biol 209: 409-433.

JEFFS, P., JAQUES, K. and OSMOND, M. (1992). Cell death in cranial neural crest development. Anat Embryol (Berl) 185: 583-588.

JEFFS, P. and OSMOND, M. (1992). A segmented pattern of cell death during development of the chick embryo. Anat Embryol (Berl) 185: 589-598.

KELLEHER, D.J. and GILMORE, R. (1997). DAD1, the defender against apoptotic cell death, is a subunit of the mammalian oligosaccharyltransferase. Proc Natl Acad Sci USA 94: 4994-4999.

KIM, H.Y., KLAUSNER, R.D. and ROUAULT, T.A. (1995). Translational repressor activity is equivalent and is quantitatively predicted by in vitro RNA binding for two iron-responsive element-binding proteins, IRP1 and IRP2. J Biol Chem 270: 4983-4986.

LAVAUTE, T., SMITH, S., COOPERMAN, S., IWAI, K., LAND, W., MEYRONHOLTZ, E., DRAKE, S.K., MILLER, G., ABU-ASAB, M., TSOKOS, M. et al. (2001). Targeted deletion of the gene encoding iron regulatory protein-2 causes misregulation of iron metabolism and neurodegenerative disease in mice. Nat Genet 27: 209-214.

LAWSON, A., SCHOENWOLF, G.C., ENGLAND, M.A., ADDAI, F.K. and AHIMA, R.S. (1999). Programmed cell death and the morphogenesis of the hindbrain roof plate in the chick embryo. Anat Embryol (Berl) 200: 509-519.

LEE, J.C. and PETER, M.E. (2003). Regulation of apoptosis by ubiquitination. Immunol Rev 193: 39-47.

LEVI, S., LUZZAGo, A., FRANCESCHINELLI, F., SANTAMBRoGIO, P., CESARENI, G. and AROSIO, P. (1989a). Mutational analysis of the channel and loop sequences of human ferritin H-chain. Biochem J 264: 381-388.

LEVI, S., SALFELD, J., FRANCESCHINELLI, F., COZZI, A., DORNER, M.H. and AROSIO, P. (1989b). Expression and structural and functional properties of human ferritin L-chain from Escherichia coli. Biochemistry 28: 5179-5184.

LI, P., NIJHAWAN, D., BUDIHARDJO, I., SRINIVASULA, S.M., AHMAD, M., ALNEMRI, E.S. and WANG, X. (1997). Cytochrome $c$ and dATP-dependent formation of Apaf-1/caspase- 9 complex initiates an apoptotic protease cas- cade. Cell 91: 479-489.

LIEM, K.F., JR., TREMML, G. and JESSELL, T.M. (1997). A role for the roof plate and its resident TGFbeta-related proteins in neuronal patterning in the dorsal spinal cord. Cell 91: 127-138.

LIEM, K.F., JR., TREMML, G., ROELINK, H. and JESSELL, T.M. (1995). Dorsa differentiation of neural plate cells induced by BMP-mediated signals from epidermal ectoderm. Cell 82: 969-979.

LINKER, C., DE ALMEIDA, I., PAPANAYOTOU, C., STOWER, M., SABADO, V., GHORANI, E., STREIT, A., MAYOR, R. and STERN, C.D. (2009). Cell communication with the neural plate is required for induction of neural markers by BMP inhibition: evidence for homeogenetic induction and implications for Xenopus animal cap and chick explant assays. Dev Biol 327: 478-486.

LINKER, C. and STERN, C.D. (2004). Neural induction requires BMP inhibition only as a late step, and involves signals other than FGF and Wnt antagonists. Development 131: 5671-5681.

MAKISHIMA, T., NAKASHIMA, T., NAGATA-KUNO, K., FUKUSHIMA, K., IIDA, H., SAKAGUCHI, M., IKEHARA, Y., KOMIYAMA, S. and NISHIMOTO, T. (1997). The highly conserved DAD1 protein involved in apoptosis is required for $\mathrm{N}$ linked glycosylation. Genes Cells 2: 129-141.

MAKISHIMA, T., YOSHIMI, M., KOMIYAMA, S., HARA, N. and NISHIMOTO, T. (2000). A subunit of the mammalian oligosaccharyltransferase, DAD1, interacts with Mcl-1, one of the bcl-2 protein family. J Biochem 128: 399-405.

MARCHAL, L., LUXARDI, G., THOME, V. and KODJABACHIAN, L. (2009). BMP inhibition initiates neural induction via FGF signaling and Zic genes. Proc Nat/ Acad Sci USA 106: 17437-17442.

MCLARREN, K.W., LITSIOU, A. and STREIT, A. (2003). DLX5 positions the neural crest and preplacode region at the border of the neural plate. Dev Biol 259: 34 47.

MURAMATSU, T., MIZUTANI, Y., OHMORI, Y. and OKUMURA, J. (1997). Comparison of three nonviral transfection methods for foreign gene expression in early chicken embryos in ovo. Biochem Biophys Res Commun 230: 376-380.

NAKASHIMA, T., SEKIGUCHI, T., KURAOKA, A., FUKUSHIMA, K., SHIBATA, Y., KOMIYAMA, S. and NISHIMOTO, T. (1993). Molecular cloning of a human cDNA encoding a novel protein, DAD1, whose defect causes apoptotic cell death in hamster BHK21 cells. Mol Cell Biol 13: 6367-6374.

NEGRON, J.F. and LOCKSHIN, R.A. (2004). Activation of apoptosis and caspase3 in zebrafish early gastrulae. Dev Dyn 231: 161-170.

NIKONOV, A.V., SNAPP, E., LIPPINCOTT-SCHWARTZ, J. and KREIBICH, G. (2002). Active translocon complexes labeled with GFP-Dad1 diffuse slowly as large polysome arrays in the endoplasmic reticulum. J Cell Biol 158: 497-506.

OZKAYNAK, E., FINLEY, D. and VARSHAVSKY, A. (1984). The yeast ubiquitin gene: head-to-tail repeats encoding a polyubiquitin precursor protein. Nature 312: 663-666.

PAPANAYOTOU, C., MEY, A., BIROT, A.M., SAKA, Y., BOAST, S., SMITH, J.C., SAMARUT, J. and STERN, C.D. (2008). A mechanism regulating the onset of Sox2 expression in the embryonic neural plate. PLoS Biol 6: e2.

PAQUETTE, N., BROEMER, M., AGGARWAL, K., CHEN, L., HUSSON, M., ERTURK-HASDEMIR, D., REICHHART, J.M., MEIER, P. and SILVERMAN, N (2010). Caspase-mediated cleavage, IAP binding, and ubiquitination: linking three mechanisms crucial for Drosophila NF-kappaB signaling. Mol Cell 37 : 172-182.

QUINTANA, C., COWLEY, J.M. and MARHIC, C. (2004). Electron nanodiffraction and high-resolution electron microscopy studies of the structure and composition of physiological and pathological ferritin. J Struct Biol 147: 166-178.

REVERSADE, B., KURODA, H., LEE, H., MAYS, A. and DE ROBERTIS, E.M (2005). Depletion of Bmp2, Bmp4, Bmp7 and Spemann organizer signals induces massive brain formation in Xenopus embryos. Development 132: 3381 3392.

REX, M., ORME, A., UWANOGHO, D., TOINTON, K., WIGMORE, P.M., SHARPE, P.T. and SCOTTING, P.J. (1997). Dynamic expression of chicken Sox2 and Sox3 genes in ectoderm induced to form neural tissue. Dev Dyn 209: 323-332.

SANDERS, E.J., PRASAD, S., HU, N. and WRIDE, M.A. (1997a). Cell death in the gastrulating chick embryo: potential roles for tumor necrosis factor-alpha (TNFalpha). Cell Death Differ 4: 188-199.

SANDERS, E.J., TORKKELI, P.H. and FRENCH, A.S. (1997b). Patterns of cell death during gastrulation in chick and mouse embryos. Anat Embryol (Berl) 195 
147-154.

SCHWARTZ, L.M., MYER, A., KOSZ, L., ENGELSTEIN, M. and MAIER, C. (1990). Activation of polyubiquitin gene expression during developmentally programmed cell death. Neuron 5: 411-419.

SHENG, G., DOS REIS, M. and STERN, C.D. (2003). Churchill, a zinc finger transcriptional activator, regulates the transition between gastrulation and neurulation. Cell 115: 603-613.

SHENG, G. and STERN, C.D. (1999). Gata2 and Gata3: novel markers for early embryonic polarity and for non-neural ectoderm in the chick embryo. Mech Dev 87: 213-216.

SILBERSTEIN, S., COLLINS, P.G., KELLEHER, D.J. and GILMORE, R. (1995). The essential OST2 gene encodes the 16-kD subunit of the yeast oligosaccharyltransferase, a highly conserved protein expressed in diverse eukaryotic organisms. J Cell Biol 131: 371-383.

SRINIVASULA, S.M., AHMAD, M., FERNANDES-ALNEMRI, T. and ALNEMRI, E.S. (1998). Autoactivation of procaspase-9 by Apaf-1-mediated oligomerization. Mol Cell 1: 949-957.

STAUB, O. and ROTIN, D. (2006). Role of ubiquitylation in cellular membrane transport. Physiol Rev 86: 669-707.

STERN, C.D. (1998). Detection of multiple gene products simultaneously by in situ hybridization and immunohistochemistry in whole mounts of avian embryos. Curr Top Dev Biol 36: 223-243.

STERN, C.D. (1999). Grafting Hensen's node. Methods Mol Biol 97: 245-253.

STERN, C.D. (2005). Neural induction: old problem, new findings, yet more questions. Development 132: 2007-2021.

STERN, C.D. (2006). Neural induction: 10 years on since the 'default model'. Curr Opin Cell Biol 18: 692-697.

STERN, C.D. and IRELAND, G.W. (1981). An integrated experimental study of endoderm formation in avian embryos. Anat Embryol 163: 245-263.

STEVENS, P.W., DODGSON, J.B. and ENGEL, J.D. (1987). Structure and expression of the chicken ferritin $\mathrm{H}$-subunit gene. Mol Cell Biol 7: 1751-1758.

STOREY, K.G., CROSSLEY, J.M., DE ROBERTIS, E.M., NORRIS, W.E. and STERN, C.D. (1992). Neural induction and regionalisation in the chick embryo. Development 114: 729-741.

STREIT, A., BERLINER, A.J., PAPANAYOTOU, C., SIRULNIK, A. and STERN, C.D. (2000). Initiation of neural induction by FGF signalling before gastrulation. Nature 406: 74-78.

STREIT, A., LEE, K.J., WOO, I., ROBERTS, C., JESSELL, T.M. and STERN, C.D. (1998). Chordin regulates primitive streak development and the stability of induced neural cells, but is not sufficient for neural induction in the chick embryo. Development 125: 507-519.

STREIT, A. and STERN, C.D. (1999). Establishment and maintenance of the border of the neural plate in the chick: involvement of FGF and BMP activity. Mech Dev 82: 51-66.

STREIT, A. and STERN, C.D. (2001). Combined whole-mount in situ hybridization and immunohistochemistry in avian embryos. Methods 23: 339-344.

STREIT, A.C. and STERN, C.D. (1997). Competence for neural induction: HGF/SF, HGF1/MSP and the c-Met receptor. Ciba Found Symp 212: 155-165.

STREIT, A., SOCKANATHAN, S., PEREZ, L., REX, M., SCOTTING, P.J., SHARPE, P.T., LOVELL-BADGE, R. and STERN, C.D. (1997). Preventing the loss of competence for neural induction: HGF/SF, L5 and Sox-2. Development 124: 1191-1202.

SUGIMOTO, A., HOZAK, R.R., NAKASHIMA, T., NISHIMOTO, T. and ROTHMAN, J.H. (1995). dad-1, an endogenous programmed cell death suppressor in Caenorhabditis elegans and vertebrates. EMBO J 14: 4434-4441.

THEIL, E.C. (1987). Ferritin: structure, gene regulation, and cellular function in animals, plants, and microorganisms. Annu Rev Biochem 56: 289-315.

THEIL, E.C. (1990). Ferritin mRNA translation, structure, and gene transcription during development of animals and plants. Enzyme 44: 68-82.

THEIL, E.C. (2003). Ferritin: at the crossroads of iron and oxygen metabolism. J Nutr 133: 1549S-1553S.

THOMSON, A.M., ROGERS, J.T. and LEEDMAN, P.J. (1999). Iron-regulatory proteins, iron-responsive elements and ferritin mRNA translation. Int J Biochem Cell Biol 31: 1139-1152.

TOKUNAGA, F., SAKATA, S., SAEKI, Y., SATOMI, Y., KIRISAKO, T., KAMEI, K., NAKAGAWA, T., KATO, M., MURATA, S., YAMAOKA, S. et al. (2009). Involvement of linear polyubiquitylation of NEMO in NF-kappaB activation. Nat Cell Biol 11: 123-132.

TORTI, F.M. and TORTI, S.V. (2002). Regulation of ferritin genes and protein. Blood 99: 3505-3516.

UWANOGHO, D., REX, M., CARTWRIGHT, E.J., PEARL, G., HEALY, C., SCOTTING, P.J. and SHARPE, P.T. (1995). Embryonic expression of the chicken Sox2, Sox3 and Sox11 genes suggests an interactive role in neuronal development. Mech Dev 49: 23-36.

VOICULESCU, O., BERTOCCHINI, F., WOLPERT, L., KELLER, R.E. and STERN C.D. (2007). The amniote primitive streak is defined by epithelial cell intercalation before gastrulation. Nature 449: 1049-1052.

VOICULESCU, O., PAPANAYOTOU, C. and STERN, C.D. (2008). Spatially and temporally controlled electroporation of early chick embryos. Nat Protoc 3: 419426.

VONICA, A. and BRIVANLOU, A.H. (2006). An obligatory caravanserai stop on the silk road to neural induction: inhibition of BMP/GDF signaling. Semin Cell Dev Biol 17: 117-132.

VORONINA, E. and WESSEL, G.M. (2001). Apoptosis in sea urchin oocytes, eggs, and early embryos. Mol Reprod Dev 60: 553-561.

WAKAMATSU, Y., MOCHII, M., VOGEL, K.S. and WESTON, J.A. (1998). Avian neural crest-derived neurogenic precursors undergo apoptosis on the lateral migration pathway. Development 125: 4205-4213.

WIJSMAN, J.H., JONKER, R.R., KEIJZER, R., VANDE VELDE, C.J., CORNELISSE, C.J. and VAN DIERENDONCK, J.H. (1993). A new method to detect apoptosis in paraffin sections: in situ end-labeling of fragmented DNA. J Histochem Cytochem 41: 7-12.

WRIDE, M.A., LAPCHAK, P.H. and SANDERS, E.J. (1994). Distribution of TNF alpha-like proteins correlates with some regions of programmed cell death in the chick embryo. Int J Dev Biol 38: 673-682.

YABU, T., KISHI, S., OKAZAKI, T. and YAMASHITA, M. (2001). Characterization of zebrafish caspase-3 and induction of apoptosis through ceramide generation in fish fathead minnow tailbud cells and zebrafish embryo. Biochem J 360: 3947.

YANG, D.C., JIANG, X., ELLIOTT, R.L. and HEAD, J.F. (2002). Antisense ferritin oligonucleotides inhibit growth and induce apoptosis in human breast carcinoma cells. Anticancer Res 22: 1513-1524.

YANG, L., ZHANG, H., HU, G., WANG, H., ABATE-SHEN, C. and SHEN, M.M (1998). An early phase of embryonic Dlx5 expression defines the rostral boundary of the neural plate. J Neurosci 18: 8322-8330.

YEO, W. and GAUTIER, J. (2003). A role for programmed cell death during early neurogenesis in Xenopus. Dev Biol 260: 31-45.

YOSHIMI, M., SEKIGUCHI, T., HARA, N. and NISHIMOTO, T. (2000). Inhibition of $\mathrm{N}$-linked glycosylation causes apoptosis in hamster BHK21 cells. Biochem Biophys Res Commun 276: 965-969.

ZAHRINGER, J., KONIJN, A.M., BALIGA, B.S. and MUNRO, H.N. (1975). Mechanism of iron induction of ferritin synthesis. Biochem Biophys Res Commun 65: 583-590 
Further Related Reading, published previously in the Int. J. Dev. Biol.

See our recent Special Issue Placenta edited by Joan S. Hunt and Kent L. Thornburg at: http://www.ijdb.ehu.es/web/contents.php?vol=54\&issue=2-3

Retinoid signalling is required for information transfer from mesoderm to neuroectoderm during gastrulation. Lloret-Vilaspasa, F., Jansen, H.J., Deroos, K., Chandraratna, R.A., Zile, M.H., Stern, C.D. and Durston, A.J. (2010) Int. J. Dev. Biol. 54: 599-608.

Life-giving caspases: revealing new roles during mouse embryo preimplantation development. Busso, D., Dominguez, C., Perez-Acle, T. and Moreno, R.D. (2010) Int. J. Dev. Biol. 54: 857-865

Head-tail patterning of the vertebrate embryo: one, two or many unresolved problems? Stern, C.D., Charité, J., Deschamps, J., Duboule, D., Durston, A.J., Kmita, M., Nicolas, J.-F., Palmeirim, I., Smith, J.C. and Wolpert, L. (2006). Int. J. Dev. Biol. 50: 3-15.

Temporospatial patterns of apoptosis in chick embryos during the morphogenetic period of development. Hirata, M. and Hall, B.K. (2000). Int. J. Dev. Biol. 44: 757-768

Early chick embryos in vitro.

Stern, C.D. and Bachvarova, R. (1997) Int. J. Dev. Biol. 41: 379-387.

5 yr ISI Impact Factor $(2009)=3.253$

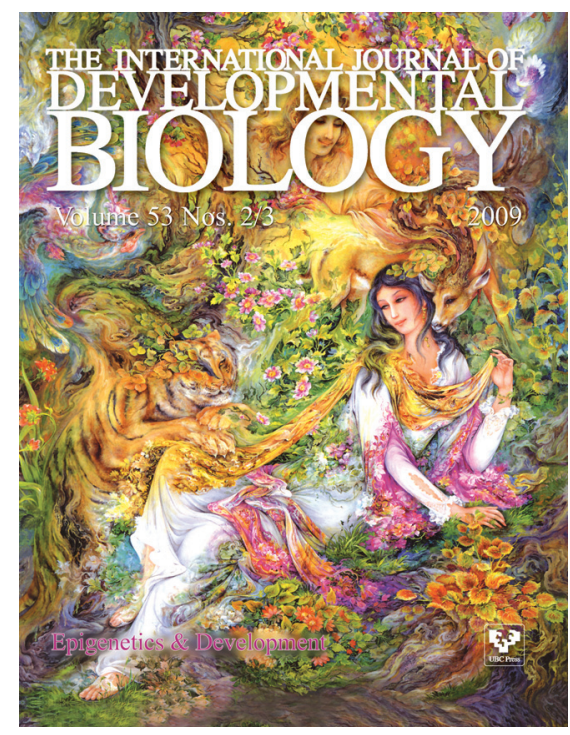

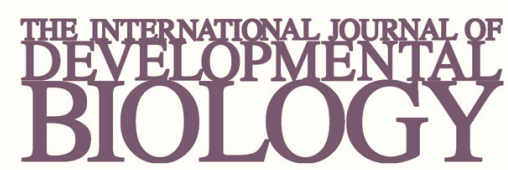

Volume 54 Nos. 6/7
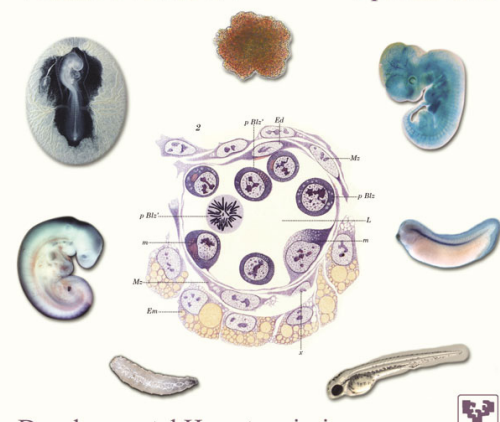

Developmental Hematopoiesis

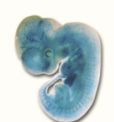

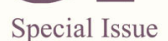

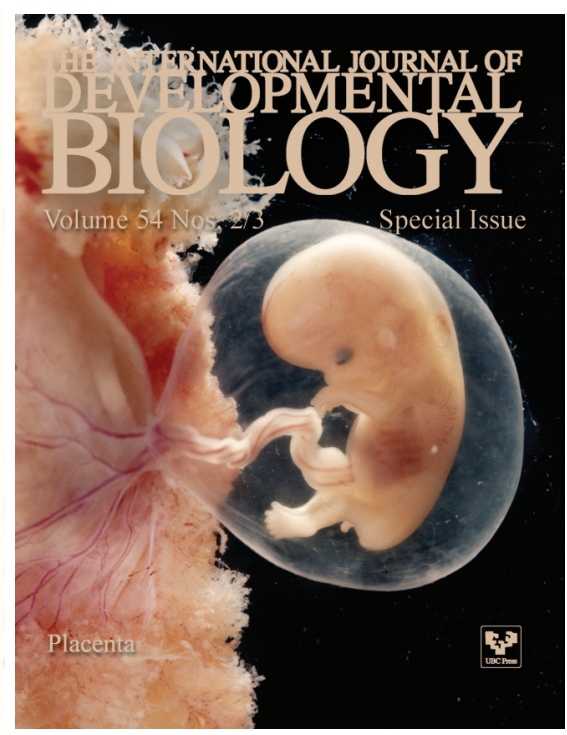

